Arq. Bras. Med. Vet. Zootec., v.68, n.5, p.1117-1120, 2016

\title{
Glycogen-rich clear cell carcinoma of the feline mammary gland: case report
}

[Carcinoma de células claras rico em glicogênio da glândula mamária felina: relato de caso]

\author{
C.B. Campos $^{1,2}$, C.O. Gamba ${ }^{1}$, K.A. Damasceno ${ }^{1}$, G.E. Lavalle $^{3}$, G.D. Cassali $^{1 *}$ \\ ${ }^{1}$ ICB-UFMG - Belo Horizonte, MG \\ ${ }^{2}$ FCAV-Unesp - Jaboticabal, SP \\ ${ }^{3}$ EV-UFMG - Belo Horizonte, MG
}

\begin{abstract}
The aim of this report is to describe the first histopathological, immunohistochemical, and clinical characteristics of a feline glycogen-rich clear cell carcinoma (GRCCC). A Persian queen was admitted with mammary gland tumors and underwent radical unilateral mastectomy. Overall survival was considered 33 days and death was due to clinical evolution of the disease. Microscopic evaluation demonstrated epithelial cells arranged in a predominantly solid pattern, tumor cells presented an ample, granular, and foamy clear cytoplasm, and moderate cellular pleomorfism. The presence of cytoplasmatic glycogen was confirmed through diastase digestion followed by PAS staining. Histopathological and histochemical findings lead to the diagnosis of GRCCC with regional metastases.
\end{abstract}

Keywords: feline, mammary gland, neoplasm, glycogen-rich clear cell carcinoma

\section{RESUMO}

O objetivo deste relato de caso é descrever as características clínicas, histopatológicas e imunohistoquímicas do primeiro carcinoma mamário de células claras rico em glicogênio em felino. Uma gata persa foi atendida com tumores na glândula mamária e foi submetida à mastectomia radical unilateral. A sobrevida livre de doença foi considerada 33 dias, e o óbito foi devido à evolução da doença. A avaliação microscópica demonstrou células epiteliais arranjadas em um padrão predominantemente sólido, as células tumorais apresentaram um citoplasma claro, amplo, granular e espumoso e pleomorfismo celular moderado. A presença do glicogênio citoplasmático foi confirmada pela digestão pela diástase, seguida da coloração de PAS. Achados histopatológicos e histoquímicos levaram ao diagnóstico de carcinoma de células claras rico em glicogênio felino com metástase regional.

Palavras-chave: glândula mamária, neoplasia, carcinoma de células claras rico em glicogênio felino

\section{INTRODUCTION}

Among all feline neoplasms, mammary neoplasms are the third most frequent, following hematopoietic and cutaneous neoplasms (Misdorp, 2002; Lana et al., 2007). Common characteristics include ulceration, lymphatic vessel invasion, and regional and distant metastasis (Lana et al., 2007). Tubular, papillary, solid, cribriform, and in situ carcinomas are considered common histological types in the feline mammary gland, and some carcinomas show a combination of patterns (Misdorp et al., 1999; Misdorp, 2002; Lana et al., 2007).

In humans, glycogen-rich clear cell carcinomas (GRCCC) are characterized by malignant epithelial cells containing an optically clear cytoplasm and intracytoplasmic glycogen (Martín-Martín et al., 2011). This diagnosis is considered rare, accounting for approximately 1 $3 \%$ of all breast carcinomas. GRCCC also arises in other organs including the lung, salivary gland, ovary, and endometrium (Rosen, 2009; Eusebi et al., 2012).

Recebido em 5 de outubro de 2015

Aceito em 29 de março de 2016

*Autor para correspondência (corresponding author)

E-mail: author: cassalig@icb.ufmg.br 
Although the GRCCC has been well described in the human mammary gland, this tumor has not been described in veterinary medicine. Therefore, the aim of this report is to describe the first histopathological, immunohistochemical, and clinical characteristics of a feline glycogenrich clear cell carcinoma.

\section{CASE REPORT}

A twelve-year-old neutered Persian queen presented painful abdominal masses, loss of appetite, and weight loss. Radiological imaging of the thorax and abdominal ultrasound failed to demonstrate distant metastasis. Fine needle aspiration cytology demonstrated the presence of malignant epithelial cells in the axillary lymph node suggesting regional metastasis. The patient underwent radical unilateral mastectomy. Overall survival was considered 33 days, defined as the period between the date of surgical removal of the tumor and death caused by the disease. The animal presented distant pulmonary metastasis with clinical signs of respiratory distress and was euthanized.

Macroscopic evaluation of the resected mammary sample demonstrated multiple focal masses in the cranial abdominal mammary gland of up to $0.5 \mathrm{~cm}$ in diameter, solid, not fixed, well demarcated and of whitish color. The caudal abdominal mammary gland presented a $5.5 \times 3.8$ $\mathrm{x} 1.2 \mathrm{~cm}$ ulcerated, irregular, and firm mass and an isolated $1.8 \times 1.3 \times 1.2 \mathrm{~cm}$ subcutaneous mass, also of firm consistency. Both masses were grossly solid, lobulated, presented a yellow color, with irregular margins. Axillary and inguinal enlarged lymph nodes were evaluated and were grossly similar to the mammary gland lesions. Samples were fixed in $10 \%$ neutral buffered formalin and embedded in paraffin. Sections were stained with $H \& E$ and periodic acid-Schiff (PAS).

Microscopic evaluation demonstrated neoplastic masses composed by epithelial cells arranged in a predominantly solid, with occasional tubular or papillary, pattern with in situ and invasive areas.
More than $75 \%$ of tumor cells presented an ample, granular, foamy, and clear cytoplasm with central and round to ovoid nucleous and prominent nucleoli, and moderate cellular pleomorfism. Diastase digestion followed by PAS staining revealed the presence of cytoplasmatic glycogen in neoplastic clear cells. According to Elston and Ellis (1998), histological grade of the primary tumors was considered grade III.

Histopathological evaluation of the regional lymph nodes demonstrated macrometastasis composed by epithelial cells. Metastatic cells were characterized by moderate pleomorfism with moderate cytoplasm, and multiple and prominent nucleoli. Extensive areas of necrosis were evidenced.

Histological sections of the primary tumors and lymph nodes were obtained for immunohistochemical analysis; details are described (Tab. 1). Results of immunohistochemical analysis are described (Tab. 2). Histopathological and histochemical findings lead to the diagnosis of GRCCC with regional metastases to the axillary and inguinal lymph nodes (Fig. $1 \mathrm{~A}$ and B).

\section{DISCUSSION}

GRCCC of the breast is defined as a carcinoma in which more than $90 \%$ of tumor cells have abundant clear cytoplasm containing glycogen (Rosen, 2009; Eusebi et al., 2012). A special type of carcinoma is defined when the characteristic features compose more than $90 \%$ of the tumor, and when the features are present in 75 to $90 \%$ of the tumor, the case may be recognized as a variant of the special type (Page et al., 1998). Therefore, the GRCCC in this study was considered as a GRCCC variant. Similar to the present case, most human patients have lymph node metastasis at the time of clinical diagnosis and tend to experience a less favorable outcome than those harboring non clear cell carcinomas (Varga and Caduff, 1999; Son et al., 2004; Rosen, 2009). 


\section{Glycogen-rich clear...}

Table 1. Target antigen and clone, dilution, antigen retrieval method, and incubation time and temperature for immunohistochemical staining for Ki-67, Estrogen Receptor (ER), Progesterone Receptor (PR), Cyclooxigenase-2 (Cox-2), Vascular Endothelial Growth Factor (VEGF), and Human Epidermal Growth Factor Receptor type 2 (HER-2)

\begin{tabular}{|c|c|c|c|}
\hline $\begin{array}{l}\text { Target Antigen } \\
\text { (Clone) }\end{array}$ & Dilution & Antigen Retrieval Method & $\begin{array}{l}\text { Incubation Time }(\mathrm{h}) / \\
\text { Temperature }\end{array}$ \\
\hline $\begin{array}{c}\mathrm{Ki}-67 \\
(\mathrm{MIB}-1)\end{array}$ & $1: 25$ & $\begin{array}{l}\text { Pressurised Heat }\left(125^{\circ} \mathrm{C} / 2 \mathrm{~min}\right) \text { with citrate } \\
\text { buffer pH } 6.0\end{array}$ & 1 / Room Temperature \\
\hline ER (1D5) & $1: 20$ & $\begin{array}{l}\text { Pressurised Heat }\left(125^{\circ} \mathrm{C} / 2 \mathrm{~min}\right) \text { with EDTA } \\
\text { buffer } \mathrm{pH} 9.0\end{array}$ & 1 / Room Temperature \\
\hline PR (HPRA2) & $1: 20$ & $\begin{array}{l}\text { Pressurised Heat }\left(125^{\circ} \mathrm{C} / 2 \mathrm{~min}\right) \text { with EDTA } \\
\text { buffer pH } 9.0\end{array}$ & 1 / Room Temperature \\
\hline $\begin{array}{c}\text { HER-2 } \\
\text { (Polyclonal) }\end{array}$ & $1: 200$ & $\begin{array}{l}\text { Water bath }\left(98^{\circ} \mathrm{C} / 20 \mathrm{~min}\right) \text { with citrate buffer } \\
\text { pH } 6.0\end{array}$ & $16 / 4^{\circ} \mathrm{C}$ \\
\hline $\begin{array}{l}\text { Cox-2 } \\
(\mathrm{SP} 21)\end{array}$ & $1: 80$ & $\begin{array}{l}\text { Water bath }\left(98^{\circ} \mathrm{C} / 20 \mathrm{~min}\right) \text { with citrate buffer } \\
\text { pH } 6.0\end{array}$ & 1 / Room Temperature \\
\hline $\begin{array}{l}\text { VEGF } \\
(\mathrm{Ab}-1)\end{array}$ & $1: 200$ & No antigen retrieval & 1 / Room Temperature \\
\hline
\end{tabular}

Table 2. Immunohistochemical results for Ki-67, Estrogen Receptor (ER), Progesterone Receptor (PR), Cyclooxigenase-2 (Cox-2), Vascular Endothelial Growth Factor (VEGF), and Human Epidermal Growth Factor Receptor type 2 (HER-2) analysis in a feline glycogen-rich clear cell carcinoma (GRCCC)

\begin{tabular}{ccccccccc}
\hline \multirow{2}{*}{ Neoplasms } & & $\begin{array}{c}\text { Ki-67 } \\
(\%)\end{array}$ & $\begin{array}{c}\text { ER } \\
(+/-)\end{array}$ & $\begin{array}{c}\text { PR } \\
(+/-)\end{array}$ & $\begin{array}{c}\text { Cox-2 } \\
(\text { score })\end{array}$ & $\begin{array}{c}\text { VEGF } \\
(\text { score })\end{array}$ & $\begin{array}{c}\text { HER-2 } \\
\text { (score })\end{array}$ \\
\hline \multirow{4}{*}{ GRCCC } & Primary & Cranial abdominal & 43 & $+^{\mathrm{a}}$ & + & 6 & 2 & $1+{ }^{\mathrm{b}}$ \\
& Neoplasms & Caudal Abdominal & 64.6 & + & + & 8 & 3 & $1+$ \\
& Regional & Axillary & 33.6 & + & + & 8 & 2 & $1+$ \\
& Lymph Nodes & Inguinal & 47.6 & + & + & 12 & 2 & $1+$ \\
\hline
\end{tabular}

Note: ${ }^{a}+=$ Nuclear staining present in $1 \%$ or more of the tumor cells, considered as positive for ER and PR, evaluation defined by the American Society of Clinical Oncology, College of American Pathologists (ASCO/CAP). ${ }^{b}$ $1+=$ Weak or incomplete membrane staining of any proportion of the tumor cells for HER-2, evaluation defined by the American Society of Clinical Oncology, College of American Pathologists (ASCO/CAP).

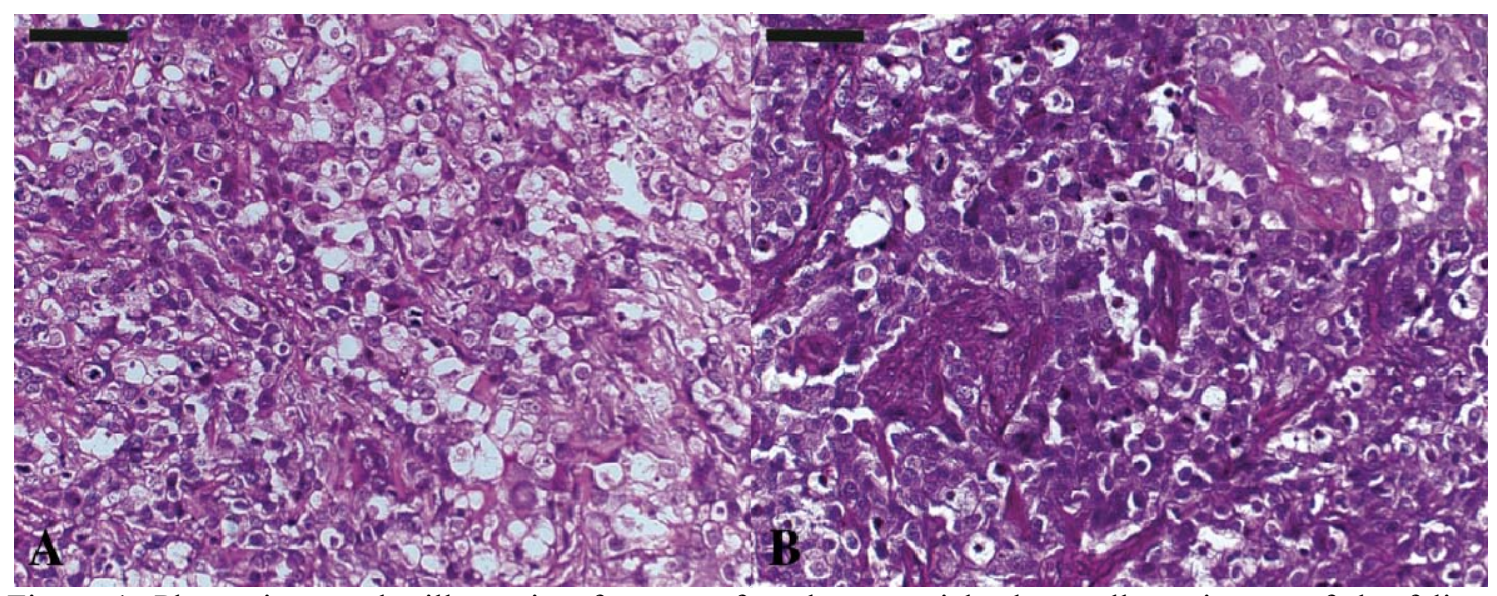

Figure 1. Photomicrographs illustrating features of a glycogen-rich clear cell carcinoma of the feline mammary gland. A. Tumor cells presenting moderate cellular pleomorphism and an ample, granular, and foamy clear cytoplasm with central and round to ovoid nucleus and prominent nucleoli. HE, 40x. Bar $=50 \mu \mathrm{m}$. B. Neoplastic epithelial clear cells presenting cytoplasmatic PAS-positive glycogen (Inset shows of PAS staining after diastase digestion). PAS, 40x. Bar $=50 \mu \mathrm{m}$. 
The diagnosis of this histological type is based on histologic and histochemical findings. as GRCCC consist predominantly of cells containing PAS-positive diastase-labile material (Mizukami et al., 2009; Rosen, 2009; Eusebi et al., 2012). Our results pointed to a poorly differentiated, high Ki-67 proliferation index, high Cox-2 scores, and VEGF overexpression, compatible with the poor prognosis associated with this tumor type in human breast cancer (Varga and Caduff, 1999; Rosen, 2009; Eusebi et al., 2012). Our PR results contradict human breast GRCCC, in which all described tumors were negative for this hormonal receptor. ER is described as positive in $50 \%$ of human cases (Rosen, 2009; Eusebi et al., 2012), and the described canine GRCCC was found to be positive. As found in our study, HER-2 scores were negative in previous studies in humans (Son et al., 2004; Mizukami et al., 2009).

\section{CONCLUSION}

Case reports on rare tumor types in veterinary oncology are important, since they provide information regarding prognosis and aid in the establishment of diagnosis and treatment. Features of GRCCC in a Persian queen seem to be similar to the same tumor types diagnosed in women, which enabled an adequate diagnosis.

\section{ACKNOWLEDGEMENTS}

This study was supported in part by the Fundação de Amparo à Pesquisa do Estado de São Paulo (FAPESP), Fundação de Amparo à Pesquisa de Minas Gerais (FAPEMIG), Conselho Nacional de Desenvolvimento Científico e Tecnológico (CNPq), and Coordenação de Aperfeiçoamento de Pessoal de Nível Superior (CAPES).

\section{REFERENCES}

ELSTON, C.W.; ELLIS, I.O. Assessment of histological grade. In: _ . (Eds.). Systemic pathology: the breast. England: Churchill Livingstone, 1998. p.365-384.

EUSEBI, V.; ICHIHARA, S.; VINCENTSALOMON, A.; et al. Exceptionally rare types of variants. In: LAKHANI, S.R.; ELLIS, I.O.; SCHNITT, S.J. (Eds.). WHO classification of tumours of the breast. France: IARC, 2012. p.122-123.

LANA, S.E.; RUTTEMAN, G.R.; WITHROW, S.J. Tumors of the mammary gland. In: WITHROW, S.J.; VAIL, D.M. (Eds.). Withrow \& MacEwen`s small animal clinical oncology. Saint Louis: W. B. Saunders Company, 2007. p.619-636.

MARTÍN-MARTÍN， B.; BERNÁ-SERNA， J.D.; SÁNCHEZ-HENAREJOS, P. et al. An unusual case of locally advanced glycogen-rich clear cell carcinoma of the breast. Case Rep. Oncol., v.4, p.452-457, 2011.

MISDORP, W. Tumors of the mammary gland. In: MEUTEN, D.J. (Ed.). Tumors in domestic animals. Iowa: State Press, 2002. p.575-606.

MISDORP, W.; ELSE, R.W.; HELLMÉN, E.; LIPSCOMB, T.P. Histological classification of mammary tumors of the dog and the cat. Washington: Armed Forces Institute of Pathology, 1999. v.7, p.159. (2.Series).

MIZUKAMI, Y.; TAKAYAMA, T.; TAKEMURA, A.; ICHIKAWA, K. Glycogen-rich clear cell carcinoma of the breast: case report. J. Med. Ultrasound, v.36, p.39-43, 2009.

PAGE, D.L.; JENSEN, R.A.; SIMPSON, J.F. Routinely available indicators of prognosis in breast cancer. Breast Cancer Res. Treat., v.51, p.195-208, 1998.

ROSEN, P.P. Glycogen-rich carcinoma. In: (Ed.). Rosen's breast pathology. New York: Lippincott Williams \& Wilkins, 2009. p.612-615.

SON, H.J.; JUNG, S.H.; LEE, S.Y.; MOON, W.S. Glycogen-rich clear cell mammary malignant myoepithelioma. Breast, v.13, p.506-509, 2004.

VARGA, Z; CADUFF, R. Glycogen-rich carcinomas of the breast display unique characteristics with respect to proliferation and the frequency of oligonucleosomal fragments. Breast Cancer Res. Treat., v.57, p.215-219, 1999. 